\title{
Assessing an Academic Library Professional Development Program
}

Karen R. Harker, Erin O’Toole, and Catherine Sassen

Copyright (C) 2018 Johns Hopkins University Press. This article first appeared in PORTAL: LIBRARIES AND THE ACADEMY, Volume 18, Issue 1, January 2018, pages 199-223.

Abstract: Professional development programs have been established in many academic libraries to support the research and scholarly activities of librarians. Continuous assessment can contribute to the sustainability and effectiveness of these programs. This study describes how measures of need, participation, satisfaction, and impact are employed to assess many aspects of a professional development program in a large academic library. Results from these assessments are used to justify the program to the library administration, continuously improve the program, and provide information about its benefits to current and potential participants.

\section{Introduction}

Research and publication requirements for many academic librarians have increased steadily since $1980 .{ }^{1}$ Unfortunately, not all library schools prepare their graduates to meet these expectations. Lili Luo studied 49 American Library Association-accredited library and information science degree programs in 2010 and found that only 61 percent required a research methods course. ${ }^{2}$ Unsurprisingly, many librarians believe themselves unequipped to conduct research. According to a study of academic librarians, only 26 percent of 815 respondents thought that their master's degree programs in library and information science "adequately prepared them to conduct original research.”3

Many academic libraries have implemented professional development programs to help librarians advance in their careers. ${ }^{4}$ For the purposes of this discussion, a professional 
development program is defined as a series of workshops, instructional sessions, and activities designed to support and encourage the research and scholarly activities of librarians. Professional development groups have been known by many names, such as "Academic Writing Group," 5 "Peer Mentoring Group," or "Research Work Group."” Some of these groups focus on the needs of tenure-track or junior librarians, such as the Junior Faculty Research Roundtable at the City University of New York. ${ }^{8}$ Other groups, such as the community of practice group at the University of Idaho in Moscow, are open to any interested individuals. ${ }^{9}$ Professional development is also a concern in higher education, as evidenced by the strategies that academic departments use to support the research activities of teaching faculty members. ${ }^{10}$

Assessment is a key element in ensuring the success of a professional development program. ${ }^{11}$ Periodic assessments can provide the information needed to determine if the program is meeting its goals and how it could be improved. Assessments also can be used to measure the impact of programming on librarians' professional development. Results from the assessments should be shared with the library administration to demonstrate the value of the program. Results also should be distributed to current and potential participants to publicize the benefits of the program.

This article describes a professional development program with a distinctive approach to assessment at the University of North Texas (UNT) Libraries in Denton. UNT is the largest public university in the Dallas-Fort Worth area with over 37,000 students. The UNT Libraries' cataloged holdings include 7 million print and digital items housed in six facilities. The libraries employ approximately 59 librarians. UNT librarians have faculty status, which makes them eligible for service on the Faculty Senate and its committees. The librarians also are eligible for development leaves, research funds, and faculty awards. The librarians are evaluated annually on 
their assigned duties, scholarship, and service. They must meet evaluation criteria in all three areas to attain promotion and continuing appointment. A professional development program for UNT librarians was created in 2010 in response to increased expectations for research and publication. The comprehensive assessment plan has been in place since 2013 .

\section{Literature Review}

When exploring professional development for academic librarians and its assessment, it is reasonable to review the literature of both higher education and librarianship. Academic librarians and teaching faculty both work to achieve the academic goals at institutions of higher education and frequently have overlapping responsibilities and privileges. A recent survey finds that 52 percent of responding institutions grant faculty status to academic librarians, with peer

evaluation and faculty senate participation being the most common characteristics of the status. ${ }^{12}$ Thus academic librarians often emulate teaching faculty as models for professional performance.

The terms "professional development," "career development," and "faculty development" are used interchangeably in the literature of higher education and librarianship to broadly describe activities with the purpose of improving research, teaching, and service. Specific activities within this realm aim to improve research skills, scholarly output, teaching and learning, application of instructional technology, collaboration, and acculturation to an institution.

For the purposes of this case study, the literature review is limited to professional development programs that mainly provide support for research and scholarly productivity. A variety of activities fall within this set, ranging from training in research methods to writing groups to guidance on selecting journals for article submission. Mentoring programs are much broader in scope and thus are excluded from this discussion. This review examines the programs 
for research and productivity support described in higher education and library and information science (LIS) literature, and the types of assessments used to measure the success of the programs.

\section{Professional Development in Higher Education and Academic Librarianship}

Writing groups for academics are a popular approach to professional development in the areas of research and scholarly output. Most writing groups organize at the school or college level, but some operate at the university level. ${ }^{13}$ Writing groups vary in meeting frequency, length, and location. For example, some take place at off-campus retreats of several days, and others hold weekly meetings on campus. ${ }^{14}$ Groups of teaching faculty often choose to have an interdisciplinary composition, ${ }^{15}$ while others prefer to have a uniform membership. ${ }^{16}$ Writing groups for library faculty have a varied composition based on the role each member plays in the library's operations, for example, collection management or public services. Some institutions cluster writing groups by broad disciplines and by the format of the work being written, meaning books, articles, grant proposals, and other formats. ${ }^{17}$ Most groups are self-managed, although Cheri Hampton-Farmer, Erin Laverick, Christine Denecker, Christine Tulley, Nicole Diederich, and Anthony Wilgus report that a senior faculty member with research experience and enthusiasm facilitates the successful writing groups at the University of Findlay in Findlay, Ohio. $^{18}$

Besides having different structures, academic writing groups participate in a variety of activities, though almost all focus on the act of writing. Teaching faculty Alison Lee and David Boud at the University of Technology Sydney in Australia have responded to new research requirements by initiating a writing group that discusses the participants' new identities as researchers to build confidence. ${ }^{19}$ Writing groups commonly invite experts to give them advice 
in areas of research and publication. The teaching faculty in the summer writing group at University of North Carolina at Chapel Hill have learned techniques for setting writing goals, putting aside time to write, and overcoming writing blocks. ${ }^{20}$ Discussions with expert writers and journal editors increase understanding of the writing style of scholars and how to decide where to submit a manuscript. ${ }^{21}$ Library faculty at RMIT (Royal Melbourne Institute of Technology) University in Melbourne, Australia, have asked campus experts on research methods and ethics to address their writing group. ${ }^{22}$ Exchange of drafts and peer critiquing often occur in writing groups for both teaching and library faculty. ${ }^{23}$ The Western Writers Coercion Group, a group of writers from five institutions in the western United States, bridges long distances by holding teleconference meetings every other week to report on writing progress, to critique one another's writing, and to hold one another accountable to their goals, as indicated by the group's name. ${ }^{24}$ Librarians at the University of North Carolina at Greensboro use the workbook, How to Write a Lot: A Practical Guide to Productive Academic Writing by Paul Silvia, to provide a framework for their workshop. ${ }^{25}$

The remaining professional development programs discovered in this review are not easily categorized, yet they all support research skills and scholarly productivity. One distinguishing factor is whether a program is composed of one focused activity or multiple activities with varied purposes. There are examples of single activity programs in both higher education and academic librarianship. The University of Tennessee College of Pharmacy in Nashville focuses on grants to facilitate research development. Early career academics at the College of Pharmacy can apply for the Individual Professional Development Program, which provides money for training or travel, and the Seed Research Grant, which provides start-up money for research. ${ }^{26}$ Teaching faculty at Anadolu University in Eskişehir, Turkey, have 
identified inconvenience as one of the biggest barriers to participation in professional development activities. ${ }^{27}$ Nilgun Ozdamar Keskin and Abdullah Kuzu have designed a mobilelearning module for professional development, with a concentration on research skills videos, that is accessible by mobile phone or tablet. More like an academic writing group is the Professional Reading Group at Leeds Beckett University in Leeds, England. ${ }^{28}$ Library faculty there have started a monthly reading group to become familiar with LIS research, to learn how to read and critique scholarly literature, and to build a foundation for starting their own research and writing.

Instances of multicomponent professional development programs that concentrate on research are more common in the literature of academic librarianship than in that of higher education. In higher education, Emma Price, Brian Coffey, and Amy Nethery have established a network for junior faculty to help them meet the demands of research and overcome isolation at Deakin University in Burwood, Australia. ${ }^{29}$ The program consists of an online forum for communication and support, a series of development workshops, and a writing retreat, with the retreat being the most successful and the online forum the least. In academic librarianship, multifaceted programs are usually led by a formal committee of librarians, either appointed or elected, and have in common the goal of preparing librarians to achieve tenure. ${ }^{30}$ Mississippi State University in Mississippi State and Texas A\&M University Libraries in College Station have held workshop series that cover similar topics: survey design, basic statistics, manuscript submission and revision, and reading and critiquing articles. ${ }^{31}$ Regularly scheduled research forums or series are an opportunity for librarians to practice for conference presentations or to present research-in-progress and obtain feedback. ${ }^{32}$ Oregon State University Libraries in Corvallis support a writing group for library faculty, along with a suite of other programs. ${ }^{33}$ The 
number of development activities available for library faculty range from two at Mississippi

State to four at Oregon State. ${ }^{34}$

\section{Assessment of Professional Development}

Administrators of professional development programs most frequently apply a survey instrument to assess participants' needs and interests, and to measure the success of development activities. To determine which research topics to address in writing groups, library faculty have distributed surveys to assess writers' perceived competence in a variety of areas, such as research methods, writing calls for proposals, and responding to peer critiques. ${ }^{35}$ Jennifer Brannock, Miao Jin, and Tisha Zelner report distributing a survey with close- and open-ended questions to identify the types of research support desired by members of the Research Work Group at the University of Southern Mississippi Libraries in Hattiesburg. ${ }^{36}$ Pre- and post-activity assessments given to members of writing groups ask participants to report their confidence levels, ${ }^{37}$ their writing abilities ${ }^{38}$ and their perceived barriers to writing and satisfaction with the program. ${ }^{39}$ Despite these examples, the majority of researchers have conducted surveys only after writing programs, which have lasted anywhere from one day to an academic year.

Two studies of writing groups stand out in this review because the researchers have adopted a more rigorous assessment strategy with ongoing and long-term surveys. Doreen Sullivan, Julia Leong, Annie Yee, Daniel Giddens, and Robyn Phillips evaluate the confidence level of library faculty in their writing group at the year's midpoint, in addition to pre- and postsurveys, to make sure the group is progressing toward its goal of increasing scholarly confidence. ${ }^{40}$ Cecilia Farr, Joanne Cavallaro, Gabrielle Civil, and Susan Cochrane have surveyed participants after each writing retreat at the College of St. Catherine (now St. Catherine University) in St. Paul, Minnesota. Upon reaching the retreat's five-year anniversary, the team 
sent a survey to all past participating teaching faculty to ask about the long-term impact of the retreats. $^{41}$

A slight majority of organizers of multicomponent programs evaluate program success using survey instruments, and like most organizers of writing groups, they only distribute surveys once after the activities are completed. Oregon State University Libraries reports a onetime, online survey with questions about research productivity and the value of activities, which was distributed to library faculty. ${ }^{42}$ This survey followed one year of participation in a development program that has four distinct activities. Teaching faculty at Deakin University in Burwood, Australia, administer a survey to participants after a writing retreat and a series of development seminars. ${ }^{43}$

The question types on surveys for participants in all development activities range from Likert rating scales that ask the respondent how much he or she agrees or disagrees with a statement, to number rating scales, to open-ended inquiries. ${ }^{44}$ Absent from many studies of development programs are verbatim survey questions or entire copies of the survey instruments. Notable exceptions are the questionnaire on participation and confidence distributed to library faculty in a research support group at Flinders University in Adelaide, Australia, ${ }^{45}$ and satisfaction surveys used to query library faculty participating in research support groups at the City University of New York and Oregon State University. ${ }^{46}$

The other common assessment of professional development programs is tracking the scholarly productivity of participants. This outcome assessment is applied more often to writing groups in which participants set and attempt to meet writing goals. Teaching faculty typically participate in stand-alone writing groups, rather than groups that are part of a multicomponent program. In some instances, they self-report their progress on drafts, submitted articles, grant 
proposals, acceptances, and awards once at the end of the writing period. ${ }^{47}$ In other programs, the administrators wait one to three years after the intervention to question teaching faculty about their productivity. ${ }^{48}$ An exception is the approach of Yvonne Steinert, Peter McLeod, Stephen Liben, and Linda Snell at McGill University, who request participants' curricula vitae (CVs) for review five years after a writing program for teaching faculty. ${ }^{49}$ This evaluation identifies the number of publications and presentations produced during the five years before the writing program and the five years after.

The tracking of scholarly production is also used to assess development programs with multiple components. Texas A\&M Libraries in College Station have a Research Committee that funds librarians' proposed research projects and a Research Forum for gathering feedback on manuscripts and presentations. ${ }^{50}$ The committee tracks how many projects that come through the two programs result in presentations or publications. The University of Tennessee College of Pharmacy also gathers data on the scholarly output of recipients of their Individual Faculty Development and Seed Research Grants. ${ }^{51}$ Missing from these studies is any type of instrument to collect self-reported productivity or to gather data from CVs. Other elements that could add rigor to monitoring scholarly activity are absent from the literature, specifically benchmarking and control groups. Only the study by Hampton-Farmer and her team uses a control group of nonparticipating faculty to assess the productivity of the faculty who participate in the Faculty Writing Group at the University of Findlay. ${ }^{52}$

\section{Summary}

Assessment of professional development programming serves several purposes for administrators and participants. It gives program administrators the data to make evidence-based decisions on improving activities and increasing participant engagement. Assessment also 
provides data about the benefits and value participants perceive in programs, which can be measured against the goals of programs. Data from assessments give administrators an evidencebased method to communicate about professional development to stakeholders. Finally, measurement of programs determines whether desired impacts or outcomes are achieved. Program assessment cannot serve these various purposes unless it is continuous, remains focused, and employs a control group or benchmark when possible. Since assessment is a difficult undertaking, professional development in all disciplines could be improved by administrators sharing in the literature the instruments and methods used to gather data.

The assessment of professional development programs for research skills and scholarly productivity hovers at a basic level in higher education and academic librarianship, and needs to achieve a more rigorous level to gain a greater understanding of programs' impacts. Both areas show a heavy reliance on one-time surveys that gather self-reported data. Most studies in this review do not apply continuous assessment with surveys or productivity tracking to determine the perception and impact of development programs over time. Several of the development programs containing multiple activities in this review use one survey to assess all activities at the end of the year. The survey is neither timely nor focused on a particular activity. Few studies use a control group or benchmark in determining whether scholarly productivity has increased in higher education and academic librarianship. Without this rigor, assessments of professional development programs will struggle to convince administrators and stakeholders of the value of the programs. Researchers can help one another achieve more rigorous assessment by sharing detailed methods and instruments, which were only found in a handful of studies in this review. 
This case study presents a unique assessment system for a professional development program designed for library faculty at a large academic library. This assessment strategy was developed to answer the following questions:

1. What is the reach of our professional development activities?

2. How are the activities received by the librarians?

3. What has been the impact of the activities on the scholarly outputs of those who attended? This strategy is rigorous, continuous, and comprehensive, being composed of multiple instruments. To provide transparency, all instruments are explained and included in the study.

\section{Assessments at UNT Libraries}

UNT Libraries' professional development program, called the Career Development Program, is multifaceted, providing both training and peer-review services. The mission is to promote and support the research, scholarship, and leadership activities of the UNT faculty librarians. The steering committee, composed of librarians of all ranks from various divisions of the library, arranges for up to five formal training sessions per year (two in each semester and one in the summer). The committee also collaborates on and supports ancillary informational sessions, such as facilitating online webinars; arranges for presentation and poster rehearsals; reviews articles and grant proposals; and supports informal interest groups. Each of these services requires different methods of assessment or evaluation. The steering committee is also interested in demonstrating the different ways in which these services impact the professional development of the librarians. The committee has, therefore, developed an evaluation program that includes multiple measures and methods, all of which are provided in the Appendix. These will be discussed in order of the annual cycle of administration of the program. 
In the late summer or early fall, at the beginning of the library's fiscal year, the committee surveys the librarians to learn of their primary interests. See the Interest Survey in the Appendix. The survey respondents are asked to rank their interests in broad topics (for example, research, publication, grants, leadership, and the like), as well as formats (for example, workshops, online webinars, and other arrangements). For each broad topic, the librarians are asked to select specific aspects. For example, under General Career Development, there are options for deciding to pursue another degree, self-motivation, and professional social networking. The respondents can provide free-form ideas for topics or formats. Furthermore, they may volunteer to teach any topic in which they have an interest and skill.

The committee uses the results of this survey to set the program for the coming year. Generally, the rank-order of the broad topics change little from year to year. They are usually in this order, with greater variation in the order of the lower ranked topics:

1. Research

2. Publication

3. Presentations

4. Grants

5. General career development

6. Leadership

7. Teaching

8. Mentoring

9. Service 


\section{Attendance Statistics}

For every program, attendance is taken by ensuring that everyone has signed an attendance form. This is not difficult to do, given that attendance is usually between 10 and 15 people. By counting not only the number of individuals but also the librarian ranks of the attendees, the committee can demonstrate that the sessions reach those with the greatest need- those in the lower librarian ranks — while not ignoring the requirements of more established librarians. The committee can also identify its core audience of librarians who attend most frequently and schedule programs around their commitments.

Table 1 is a sample of the attendance data the committee gathered over one year. Because we were especially interested in the degree of impact the program has had on our newest librarians, those in the assistant librarian rank, the attendance data were analyzed by both rank and frequency of attendance.

[Table 1]

Session Survey

After each session, an invitation to participate in an online survey is sent by e-mail to each attendee with three Likert-scale questions and a free-response item:

1. How beneficial to your scholarly, professional or service activities do you feel this session was? Answers on the scale range from 0 (not beneficial at all) to 8 (could not succeed without it).

2. How much of the information presented in this session was new to you? Answers on the scale range from 0 (none of it) to 8 (all of it).

3. How much will the information presented in this session change what you do? Answers on the scale range from 0 (no change at all) to 8 (changes what I do completely). 
4. Please provide any additional feedback or comments about the session.

For the complete Session Survey, see the instrument in the Appendix. To date, about 60 to 80 percent of attendees have responded to the surveys, with scores generally higher on questions 1 and 2 (benefits and impact) than on question 3 (newness of the content). An example of the analysis performed on session data is displayed in Table 2. The open-ended comments have enabled us to adjust programming to better meet the needs of the participants. Because these surveys are continuous, we can respond quickly to concerns. For example, we adjusted the timing of our programs in response to comments about scheduling concerns.

[Table 1]

Peer Reviewer Service Survey

The committee offers librarians the opportunity to have their manuscripts critiqued by a peer reviewer pool before they are sent to journal editors. A pool of eight volunteer reviewers will provide constructive criticism within two weeks of manuscript receipt. Besides journal article manuscripts, the reviewers also have given feedback on survey instruments and presentation rehearsals. The committee sends the Peer Reviewer Service Survey (see the Appendix) to the recipient of the service with questions like those in the session survey, excluding the newness question. Because these services are more personal and tailored to the respondents, the response rate has been 100 percent, and the scores are generally higher than those in the Session Survey.

[Table 2 ]

\section{Activities Survey}

So far, this discussion has described evaluation methods and measures that are direct and typical of program assessment. The committee, however, wants to measure the potential impact that the programs and services have had on those who have participated. Given that the mission 
explicitly states research and scholarship activities, the committee has decided to assess the impact on these activities directly, comparing the quality and quantity of those who attended sessions and with a control group of librarians who did not partake of the development services. The committee obtained Institutional Review Board approval to conduct a survey of these activities. The first year, the committee sent a survey asking participants to provide counts of activities in various categories, notably along dimensions of geographic scope, format, and peer review. This survey was burdensome to the respondents, and thus, response rates were low and the responses not necessarily valid. The second year, the committee asked librarians merely to allow the committee to review their CVs, which were submitted to the peer-evaluation committee for their annual reviews. This increased inter-rater reliability due in part to the smaller number of raters (four rather than each respondent), and the ability of the raters to confer and discuss differences in scoring. However, the number of librarians who allowed review of their CVs was still low. Starting in 2016, all librarian faculty will be required to maintain their CVs via a publicly accessible site at the university, the Faculty Information Service. This will allow the committee to survey the CVs without seeking consent. The committee will evaluate CVs immediately after the documentation is due for annual reviews, thus ensuring that all are updated through the previous fiscal year.

After two years of testing the Librarian Activity Survey, in the Appendix, the committee has found that the following categories can be applied to consistently identify scholarly activities on $\mathrm{CVs}$ by the raters:

\section{- Presentations}

Local (including regional within the state)

○ State 
- Multistate regional

- National

○ International

- Editing publications

○ Books

- Book chapters

○ Journals

- Articles (peer reviewer)

- Publications (whole work)

○ Books

- Book chapters

○ Peer-reviewed journal articles

○ Invited journal articles

The number of activities in the CVs are counted along three dimensions: geographic scope, format, and level of peer review. The assumption is that longer formats and greater levels of review are more rigorous and indicative of greater expertise than shorter formats or lower levels of review. Because few development sessions address leadership, these activities are not included in the survey. Comparisons of the quantities of activities completed within the year are made between those who attended at least one session or requested peer-review service at least once in each year, and those who did neither. The committee also compares the activities of those who attended fewer than the median number of sessions attended, and those who attended more than the median, to establish a gradient of impact. Table 4 is an example of impact analysis of data from one year of librarian participation in the professional development program. 
Eighteen librarians participated, and those who came to more than five events had a slightly higher average of presentations over the evaluation year.

\section{[Table 3 ]}

In future iterations, the committee will address some limitations to this method. The categories need to be more clearly defined so that they represent all scholarly activities and are mutually exclusive. Furthermore, there is a time lag between attendance and outcome. The impact of attendance on the scholarly activities may be much later than within that same year. Thus, the committee will consider such methods as comparing outcomes based on attendance in previous years. Finally, we must consider the relatively slow pace of scholarly activities, with outputs taking months or years to produce. One option the committee will consider is evaluating activities, and possibly attendance, on a rolling three-year period.

\section{Annual Report}

The assessment cycle of the professional development program concludes with an annual report. The committee prepares a report that summarizes the results of all assessments conducted during the academic year. They submit this report to the library administration and archive it in the shared file server. The purpose of the report is to demonstrate the effectiveness of the committee and the impact of the services on the development of the librarian faculty. Thus far, the library administration has supported the committee's efforts, demonstrated by the recent renewal of the group's official charge.

\section{Conclusion}

Assessment can contribute to the success of a professional development program in several ways. Continuous assessment provides accountability to stakeholders. ${ }^{53}$ Measures of need, participation, satisfaction, and impact should be included in regular reports sent to the library 
administration to justify the value of the program. Assessment reports also should be shared with current and potential participants to demonstrate the benefits of the program. Assessment also can be used to improve the quality of the program and enable it to meet participants' needs. The periodic survey of librarians' professional development interests allows the coordinators to plan programs to meet changing expectations. Regular measurement of participants' satisfaction also provides information that can be used to improve the relevance and quality of programming.

More research is needed to determine the most effective methods to use in assessing professional development programs. Attention should be focused on measuring the impact of programming on scholarly productivity, as well as testing the validity of any assessment instruments used. The current methodology opens a discussion on the value of continuous assessment using multiple measures. Because this is a new strategy, the profession would benefit from the sharing of results from future studies using this or a similar methodology. Even greater value would be realized through sharing of assessment instruments to encourage standardization and replication of research.

High-quality professional development programs play a vital role in the success of librarians, libraries, and the profession. Professional development is critical for academic librarians because it affects their research productivity, career advancement, and job satisfaction. Professional development is important for academic libraries because it affects their ability to nurture and retain quality staff. Furthermore, professional development affects librarianship because it influences the quality of scholarship in the profession.

Karen R. Harker is a collection assessment librarian at the University of North Texas Libraries in Denton; she may be reached by e-mail at: Karen.Harker@unt.edu. 
Erin O'Toole is a science reference librarian at the University of North Texas Libraries in Denton; she may be reached by e-mail at: Erin.OToole@unt.edu.

Catherine Sassen is the principal catalog librarian at the University of North Texas Libraries in Denton; she may be reached by e-mail at: catherine.sassen@unt.edu.

\section{Appendix}

\section{Interest Survey}

Welcome! The Career Development Committee at the University of North Texas Libraries is conducting this study to learn more about the topics that you would like to have covered. To plan programs, we would like to know the topics in which you have the greatest interest so that we can cover them first. We also would like your feedback on other activities that you would like the Career Development Committee to offer.

Before agreeing to participate in this research study, it is important that you read and understand the following explanation of the purpose, benefits and risks of the study and how it will be conducted.

Title of study: Career Development Survey Investigators:

- $\quad$ Catherine Sassen, University of North Texas Libraries

· $\quad$ Karen Harker, University of North Texas Libraries

- Mark McKnight, University of North Texas Libraries 
- $\quad$ Erin O'Toole, University of North Texas Libraries

- Maristella Feustle, University of North Texas Libraries

Purpose of the study: You are being asked to participate in a research study which concerns your interest in career development activities in the University of North Texas Libraries.

Study procedures: You will be asked to respond to a survey that will take about 5 to 10 minutes of your time.

Foreseeable risks: No foreseeable risks are involved in this study.

Benefits: This study may benefit you directly by enabling the Career Development Committee to plan activities that directly support your career development needs.

Compensation for participants: None

Procedures for maintaining confidentiality of research records: The survey is not collecting any information that can connect your responses to you. The confidentiality of your individual information will be maintained in any publications or presentations regarding this study. Questions about the study: If you have any questions about the study, you may contact Catherine Sassen at catherine.sassen@unt.edu.

Review for the protection of participants: This research study has been reviewed and approved by the University of North Texas Institutional Review Board (IRB). The University of North Texas IRB can be contacted at 940-565-3940 with any questions regarding the rights of research subjects.

Research participants' rights: Your participation in the survey confirms that you have read all of the above and that you agree to all of the following:

- Catherine Sassen has explained the study to you and you have had an opportunity to contact her with any questions about the study. You have been informed of the possible benefits and the 
potential risks of the study.

- You understand that you do not have to take part in this study, and your refusal to participate or your decision to withdraw will involve no penalty or loss of rights or benefits. The study personnel may choose to stop your participation at any time.

- You understand why the study is being conducted and how it will be performed.

- You understand your rights as a research participant and you voluntarily consent to participate in this study.

- You understand you may print a copy of this form for your records.

1. This message is the informed consent notice. By clicking on the "I agree" response below, you are giving your consent to participate in the survey.

I agree, and I wish to participate in the survey.

[Skip logic: If "I agree, and I wish to participate" is not selected, then skip to end of survey.] 
2. Which topics should be covered in Career Development meetings? Please rank the following items in order of your interest.

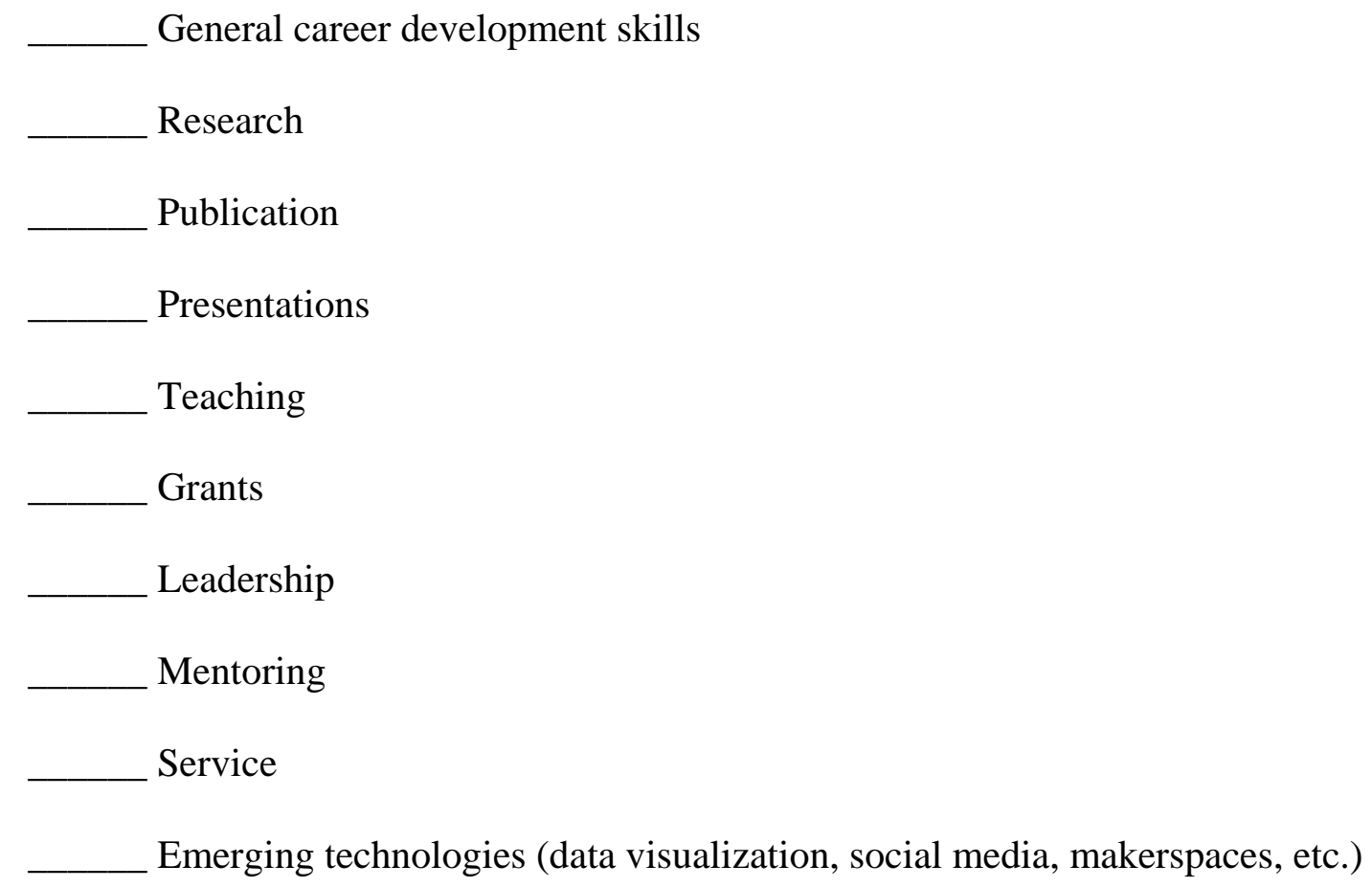

3. Which specific topics should be covered?

General career development skills

․ Professional career development plans

Deciding to pursue another degree

․ Self-motivation

a Academic writing skills

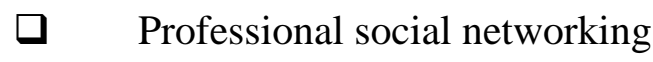

a Managing and/or writing for blogs

․ Work-life balance

․ Time management

갈 $\quad$ Proct management 
4. Which specific topics should be covered?

Research, publication and presentations

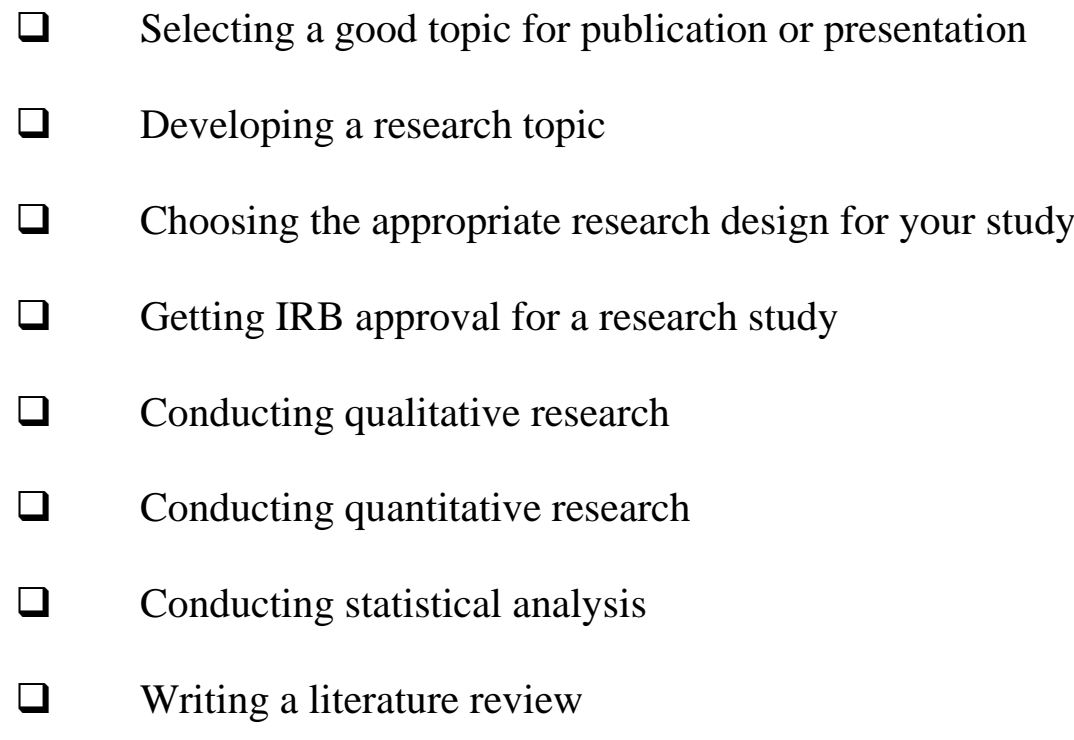

- Publishing: choosing the appropriate journal, preparing the manuscript, writing the cover letter, knowing what to expect in the submission, peer review, revision and resubmission processes

Writing a proposal for a conference presentation or poster

ㅁ Delivering a conference presentation

口 Creating a poster and participating in a poster session

Collaborating with others on publications or presentations

5. Which specific topics should be covered?

Emerging technologies

$\begin{array}{ll}\square & \text { Data visualization } \\ \square & \text { Mapping } \\ \square & \text { Visual design (e.g. Photoshop etc.) } \\ \square & \text { Coding or programming }\end{array}$ 
$\square \quad$ Social media technologies (e.g. Twitter, blog design, etc.)

口 Makerspace / Factory

6. Which specific topics should be covered?

Teaching

$\square \quad$ Serving as an adjunct faculty member

ㄴ Using effective teaching techniques

$\square \quad$ Using technology in your teaching

$\square \quad$ Assessment of learning

7. Which specific topics should be covered?

Grants

$\square \quad$ Identifying appropriate grants for your research

$\square \quad$ Writing a grant proposal

$\square \quad$ Managing grant-funded projects

8. Which specific topics should be covered?

Leadership

$\square \quad$ Developing overall leadership skills

$\square \quad$ Running efficient meetings

$\square \quad$ Setting goals

$\square \quad$ Motivating your committee

$\square \quad$ Coming to consensus

9. Which specific topics should be covered?

Mentoring

口 Choosing a mentor 
G Getting the most out of a mentoring arrangement

Being a good mentee

․ Being a good mentor

10. Which specific topics should be covered?

Service

․ Networking with other professionals

ㅁ Serving on professional association committees

$\square \quad$ Serving on university committees

글 Finding community service opportunities appropriate for your career path

G Getting started in consulting

11. Please identify other topics of interest to you:

12. Would you be willing to make any presentations to the librarians on any topics mentioned in this survey? If so, please identify the topic(s) and include your name.

13. What types of programs and activities should be offered by the Career Development Program? Please rank the following in order of your interest

Presentations

Workshops

Panel discussions

Presentation rehearsals

Discussions of journal articles pertaining to research and publication

Brainstorming about research study ideas

Writing groups that provide feedback on drafts of articles 
model)

Other:

14. How often should Career Development programs be held?

Once a month

Once every other month

Other:

15. Would you be interested in meeting with a group focused on developing leadership skills?

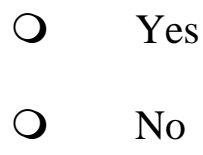

16. Would you be willing to meet with a group focused on developing research methods skills?

$\begin{array}{ll}\text { Y } & \text { Yes } \\ \text { No }\end{array}$

\section{Session Survey}

Before agreeing to participate in this research study, it is important that you read and understand the following explanation of the purpose, benefits and risks of the study and how it will be conducted.

Title of Study: Career Development Session Feedback Survey

Investigators:

- Catherine Sassen, University of North Texas Libraries

- Karen Harker, University of North Texas Libraries

- Mark McKnight, University of North Texas Libraries 
- $\quad$ Erin O'Toole, University of North Texas Libraries

- Maristella Feustle, University of North Texas Libraries

Purpose of the study: You are being asked to participate in a research study which concerns your interest in career development activities in the University of North Texas Libraries and the effectiveness of the sessions provided.

Study procedures: You will be asked to respond to a survey after attending a session that will take about three to five minutes of your time.

Foreseeable risks: No foreseeable risks are involved in this study.

Benefits: This study may benefit you directly by enabling the Career Development Committee to plan activities that directly support your career development needs.

Compensation for participants: None

Procedures for maintaining confidentiality of research records: The survey is not collecting any information that can connect your responses to you. The confidentiality of your individual information will be maintained in any publications or presentations regarding this study. Questions about the study: If you have any questions about the study, you may contact Catherine Sassen at catherine.sassen@unt.edu.

Review for the protection of participants: This research study has been reviewed and approved by the University of North Texas Institutional Review Board (IRB). The University of North Texas IRB can be contacted at 940-565-3940 with any questions regarding the rights of research subjects.

Research participants' rights: Your participation in the survey confirms that you have read all of the above and that you agree to all of the following: 
- Catherine Sassen has explained the study to you and you have had an opportunity to contact her with any questions about the study. You have been informed of the possible benefits and the potential risks of the study.

- You understand that you do not have to take part in this study, and your refusal to participate or your decision to withdraw will involve no penalty or loss of rights or benefits. The study personnel may choose to stop your participation at any time.

- You understand why the study is being conducted and how it will be performed.

- You understand your rights as a research participant and you voluntarily consent to participate in this study.

- You understand you may print a copy of this form for your records.

This message is the informed consent notice. By clicking on the "I agree" response below, you are giving your consent to participate in the survey.

I do not wish to participate.

I I agree and wish to participate in the survey.

\section{Session Attended}

- Training session on Writing Literature Reviews, September 2013

○ Panel on Research and Publication, November 2013

○ Workshop on Preparing and Giving a Presentation, January 2014

○ Workshop on Writing a Literature Review, March 28, 2014

○ Academic Writing Skills, May 27, 2014

○ Conducting Effective Surveys Workshop (part 1), June 13, 2014

○ Conducting Effective Surveys Workshop (part 2), June 20, 2014

○ Committee Leadership presentation, Sept. 11, 2014 
○ Developing Research Topics and Questions, Nov. 3, 2014

○ Basic and Advanced Networking, Jan. 27, 2015

○ Writing Books and Book Chapters, April 23, 2015

- Academic Publishing, May 20, 2015

○ IRB Review Process, July 29, 2015

- Grants, September 29, 2015

○ Panel Presentations, November 5, 2015 
- Productive Writing Strategies, Jan. 19, 2016

○ Breaking into Publishing, March 29, 2016

○ Effective Teaching Techniques, May 16, 2016

- Poster Training Session, June 17, 2016

○ Designing Posters with Inkscape and GIMP (GNU Image Manipulation Program), Oct. 27, 2016

○ How to Make a Great Presentation, Nov. 7, 2016

How beneficial to your scholarly, professional, or service activities do you feel this session was?

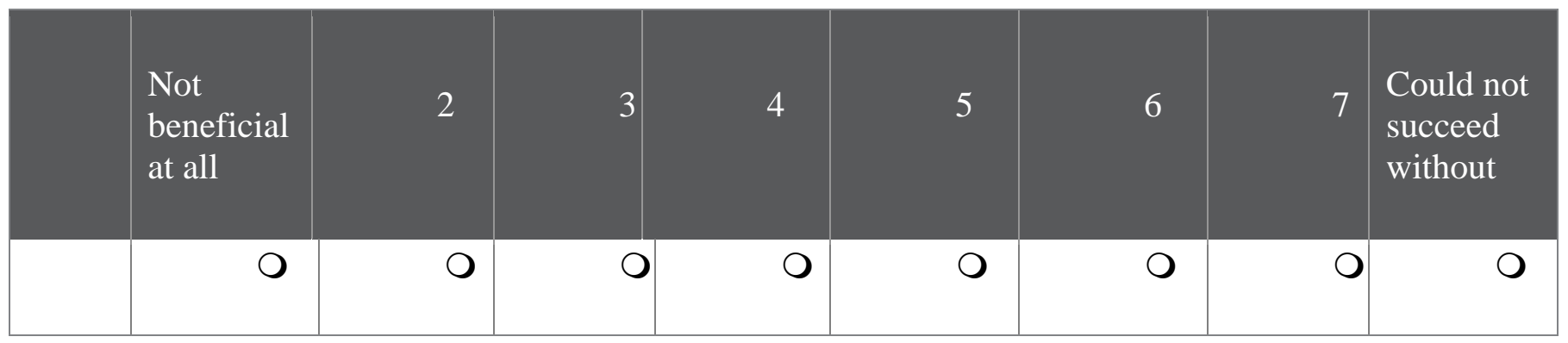

How much of the information presented in this session was new to you?

\begin{tabular}{|l|l|l|l|l|l|l|l|l|}
\hline $\begin{array}{l}\text { None of } \\
\text { it }\end{array}$ & ( & & 3 & 4 & 5 & 6 & $\begin{array}{l}\text { All of } \\
\text { it }\end{array}$ \\
\hline & & 0 & 0 & 0 & 0 & 0 & 0 \\
\hline
\end{tabular}

How much will the information presented in this session change what you do?

\begin{tabular}{|l|l|l|l|l|l|l|l|}
\hline $\begin{array}{l}\text { No } \\
\text { change } \\
\text { at all }\end{array}$ & 2 & 3 & 4 & 5 & 6 & $\begin{array}{l}\text { Changes } \\
\text { what I do } \\
\text { completely }\end{array}$ \\
\hline O & O & O & 0 & 0 & 0 & 0 & 0 \\
\hline
\end{tabular}


Please provide any additional feedback or comments about this session that you would like to make.

\section{Peer Reviewer Service Survey}

Before agreeing to participate in this research study, it is important that you read and understand the following explanation of the purpose, benefits and risks of the study and how it will be conducted.

Title of study: Peer Reviewer Service Survey

Investigators:

- $\quad$ Catherine Sassen, University of North Texas Libraries

· $\quad$ Karen Harker, University of North Texas Libraries

- Mark McKnight, University of North Texas Libraries

· $\quad$ Erin O'Toole, University of North Texas Libraries

- Maristella Feustle, University of North Texas Libraries

Purpose of the study: You are being asked to participate in a research study which concerns your feedback on the effectiveness of the Peer Reviewer Service offered by University of North Texas Libraries Career Development Program.

Study procedures: You will be asked to respond to a survey after using the Peer Reviewer Service. The survey will take about three to five minutes of your time.

Foreseeable risks: No foreseeable risks are involved in this study.

Benefits: This study may benefit you directly by enabling the Career Development Committee to modify the Peer Reviewer Service to better support your needs for peer review. Compensation for participants: None 
Procedures for maintaining confidentiality of research records: The survey is not collecting any information that can connect your responses to you. The confidentiality of your individual information will be maintained in any publications or presentations regarding this study. Questions about the study: If you have any questions about the study, you may contact Catherine Sassen at catherine.sassen@unt.edu.

Review for the protection of participants: This research study has been reviewed and approved by the University of North Texas Institutional Review Board (IRB). The University of North Texas IRB can be contacted at 940-565-3940 with any questions regarding the rights of research subjects.

Research participants' rights: Your participation in the survey confirms that you have read all of the above and that you agree to all of the following:

- Catherine Sassen has explained the study to you and you have had an opportunity to contact her with any questions about the study. You have been informed of the possible benefits and the potential risks of the study.

- You understand that you do not have to take part in this study, and your refusal to participate or your decision to withdraw will involve no penalty or loss of rights or benefits. The study personnel may choose to stop your participation at any time.

- You understand why the study is being conducted and how it will be performed.

- You understand your rights as a research participant and you voluntarily consent to participate 
in this study.

- You understand you may print a copy of this form for your records.

This message is the informed consent notice. By clicking on the "I agree" response below, you are giving your consent to participate in the survey.

I do not wish to participate.

I agree and wish to participate in the survey.

[Skip logic: If "I do not wish to participate" is selected, then skip to end of survey.] 
How beneficial to your paper was the feedback that you received through the Peer Reviewer Service?

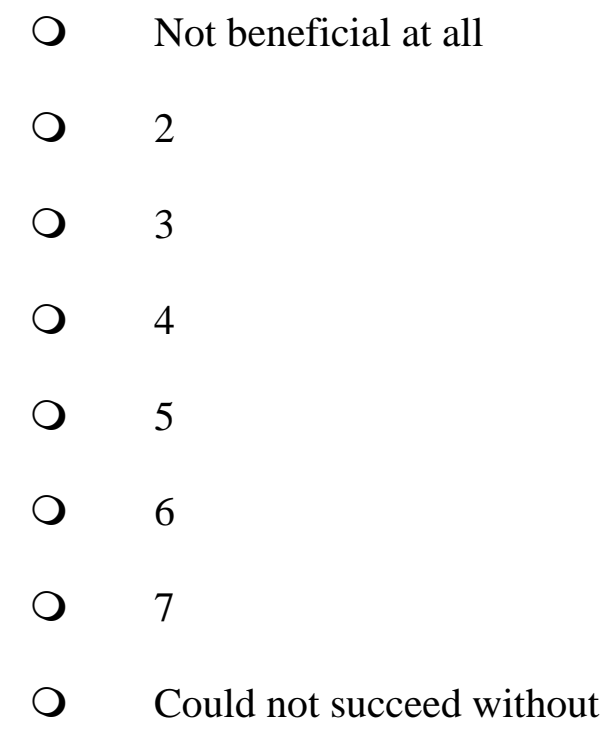

How much will the feedback change what you do?

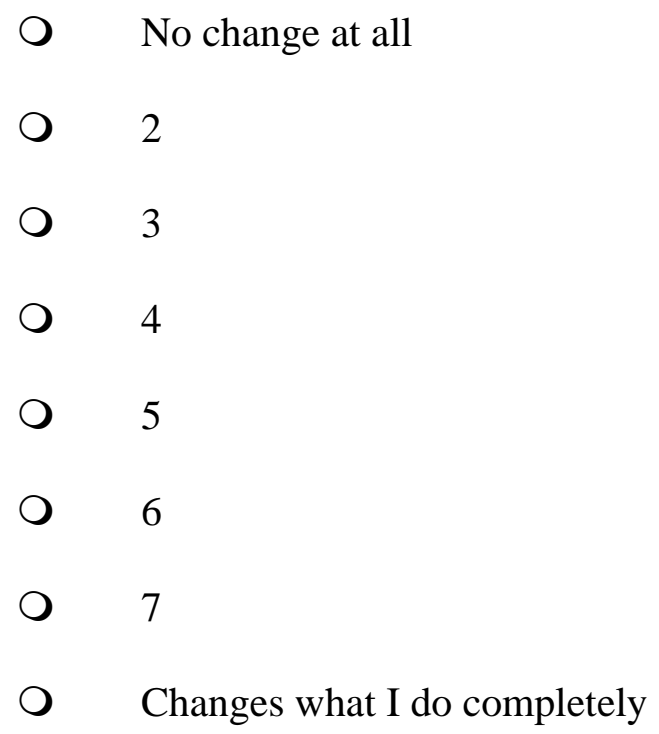

Please provide any additional comments about the Peer Reviewer Service that you would like to make.

\section{Librarian Activity Survey}


Title of study: Career Development Program Study: Librarian Activity Survey

This is an internal data collection form that the Career Development Workgroup will use to summarize information found on librarians' CVs.

Enter the name of the librarian (Last name, first name).

Please indicate the number of posters presented at conferences or meetings made between [date] and [date].

Regional (within state)
Statewide
Multistate regional
National
International

Please indicate the number of presentations at conferences or meetings made between [date] and [date].

Regional (within state)
Statewide
Multistate regional
National
International

Please indicate the number of contributions to conferences proceedings formally published between [date] and [date].

Regional (within state)

Statewide

Multistate regional 
_ National

Please indicate the number of writings formally published between [date] and [date]. Books

Book chapters

Peer-reviewed journal articles

Non-peer reviewed journal articles

Please indicate the number of publications (e.g. journals, books) for which the person served as an editor between [date] and [date].

Books

Journals

Please indicate the number of individual articles/chapters for which the person was responsible as an editor between [date] and [date].

Book chapters

Journal articles

Please indicate the number of publications (e.g. journals, books) for which the person served on the editorial board (or similarly-worded context) between [date] and [date].

Books

Journals

Please indicate the number of individual articles/chapters for which the person was responsible as on the editorial board between [date] and [date].

Book chapters

Journal articles 
Please indicate the number of publications (e.g. journals, books) for which the person served as a peer reviewer between [date] and [date].

Books

Journals

Please indicate the number of individual articles/chapters for which the person was responsible as a peer reviewer between [date] and [date].

Book chapters

Journal articles

\section{Notes}

1. Catherine Sassen and Diane Wahl, "Fostering Research and Publication in Academic Libraries," College \& Research Libraries75, 4 (2014): 466-67, doi:10.5860/crl.75.4.458.

2. Lili Luo, "Fusing Research into Practice: The Role of Research Methods Education," Library \& Information Science Research 33, 3 (2011): 191-201, doi:10.1016/j.lisr.2010.12.001.

3. Marie R. Kennedy and Kristine R. Brancolini, "Academic Librarian Research: A Survey of Attitudes, Involvement, and Perceived Capabilities," College \& Research Libraries 73, 5 (2012): 431-48, doi:10.5860/crl-276.

4. Sassen and Wahl, "Fostering Research and Publication," 461-62.

5. Cynthia Tysick and Nancy Babb, "Writing Support for Junior Faculty Librarians: A Case Study," Journal of Academic Librarianship 32, 1 (2006): 94-100, doi:10.1016/j.acalib.2005.10.005.

6. Allison V. Level and Michelle Mach, "Peer Mentoring: One Institution's Approach to Mentoring Academic Librarians," Library Management 26, 6-7 (2005): 301-10, doi:10.1108/01435120410609725. 
7. Jennifer Brannock, Miao Jin, and Tisha Zelner, "Researching Your Way out of a Paper Bag:

Supporting Research Interests in an Academic Library," Tennessee Libraries 56, 2 (2006): 7-

12, http://c.ymcdn.com/sites/www.tnla.org/resource/resmgr/imported/brannock562.pdf.

8. Jill Cirasella and Maura A. Smale, "Peers Don’t Let Peers Perish: Encouraging Research and Scholarship among Junior Library Faculty,” Collaborative Librarianship 3, 2 (2011): 98109, http://digitalcommons.du.edu/collaborativelibrarianship/vol3/iss2/5.

9. Kristin J. Henrich and Ramirose Attebury, "Communities of Practice at an Academic Library: A New Approach to Mentoring at the University of Idaho," Journal of Academic Librarianship 36, 2 (2010): 158-65, doi:10.1016/j.acalib.2010.01.007.

10. Carole J. Bland, Anne Marie Weber-Main, Sharon Marie Lund, and Deborah A. Finstad, The Research-Productive Department: Strategies from Departments That Excel (Bolton, MA: Anker, 2005).

11. Carole J. Bland, Anne L. Taylor, S. Lynn Sholen, Anne Marie Weber-Main, and Patricia A. Mulcahy, Faculty Success through Mentoring: A Guide for Mentors, Mentees, and Leaders, American Council on Education Series in Higher Education (Lanham, MD: Rowman \& Littlefield, 2011), 42.

12. William H. Walters, "Faculty Status of Librarians at U.S. Research Universities," Journal of Academic Librarianship 42, 2 (2016): 161-71, doi:10.1016/j.acalib.2015.11.002.

13. Sharon Cumbie, Clarann Weinert, Susan Luparell, Virginia Conley, and James Smith, “Developing a Scholarship Community,” Journal of Nursing Scholarship 37, 3 (2005): 289-93, doi:10.1111/j.1547-5069.2005.00049.x; Debra L. Franko, “From Nothing to Something: The Nuts and Bolts of Building a Mentoring Program in a Health Sciences College," Mentoring \& Tutoring: Partnership in Learning 24, 2 (2016): 109-23, 
doi:10.1080/13611267.2016.1178962; Jennifer Herman, Maria Abate, and Tricia Elam Walker, "Faculty Writing Retreat: Fostering Writing Productivity, Collaboration, and Community-Building through an Interdisciplinary, Multi-Day Program," International Journal of University Teaching and Faculty Development 4, 4 (2013): 193-203, https://libproxy.library.unt.edu/login?url=http://search.proquest.com/docview/1682846394?a ccountid=7113.

14. Nina Exner and Amy Harris Houk, "Starting the Write Way: Comparing Two Library Scholarly Development Programs," Library Leadership \& Management 24, 4 (2010): 17882, https://journals.tdl.org/llm/index.php/llm/article/view/1854/1127; Cecilia Konchar Farr, Joanne Cavallaro, Gabrielle Civil, and Susan Cochrane, "Taming the Publishing Beast: The College of St. Catherine Scholars' Retreat," Change: The Magazine of Higher Learning 41, 3 (2009): 14-19, doi:10.3200/CHNG.41.3.14-19; Herman, Abate, and Walker, "Faculty Writing Retreat."

15. Herman, Abate, and Walker, "Faculty Writing Retreat"; Angela Dwyer, Bridget Lewis, Fiona McDonald, and Marcelle Burns, "It's Always a Pleasure: Exploring Productivity and Pleasure in a Writing Group for Early Career Academics," Studies in Continuing Education 34, 2 (2012): 129-44, doi:10.1080/0158037X.2011.580734.

16. Yvonne Steinert, Peter J. McLeod, Stephen Liben, and Linda Snell, "Writing for Publication in Medical Education: The Benefits of a Faculty Development Workshop and Peer Writing Group,” Medical Teacher 30, 8 (2008): e280-85, doi:10.1080/01421590802337120; Teresa Stone, Tracy Levett-Jones, Margaret Harris, and Peter M. Sinclair, "The Genesis of 'The Neophytes': A Writing Support Group for Clinical Nurses," Nurse Education Today 30, 7 (2010): 657-61, doi:10.1016/j.nedt.2009.12.020. 
17. Farr, Cavallaro, Civil, and Cochrane, "Taming the Publishing Beast"; Eric L. Muller, “Developing the Faculty as a Writing Community," Academe 100, 6 (2014): 20-23, https://www.aaup.org/article/developing-faculty-writing-community\#.WMBSRzvyuUl.

18. Cheri Hampton-Farmer, Erin Laverick, Christine Denecker, Christine Tulley, Nicole Diederich, and Anthony Wilgus, "Growing a Faculty Writing Group on a Traditionally Teaching-Focused Campus: A Model for Faculty Development,” Journal of Faculty Development 27, 1 (2013): 56-62, http://www.ingentaconnect.com/contentone/nfp/jfd/2013/00000027/00000001/art00008.

19. Alison Lee and David Boud, "Writing Groups, Change and Academic Identity: Research Development as Local Practice," Studies in Higher Education 28, 2 (2003): 187-200, doi:10.1080/0307507032000058109.

20. Muller, "Developing the Faculty as a Writing Community."

21. Helen Fallon, “A Writing Support Programme for Irish Academic Librarians,” Library Review 58, 6 (2009): 414-22, doi:10.1108/00242530910969776; Steinert, McLeod, Liben, and Snell, "Writing for Publication in Medical Education."

22. Doreen Sullivan, Julia Leong, Annie Yee, Daniel Giddens, and Robyn Phillips, “Getting Published: Group Support for Academic Librarians,” Library Management 34, 8-9 (2013): 690-704, doi:10.1108/LM-03-2013-0026.

23. Exner and Houk, "Starting the Write Way"; Hampton-Farmer, Laverick, Denecker, Tulley, Diederich, and Wilgus, “Growing a Faculty Writing Group on a Traditionally TeachingFocused Campus."

24. Cumbie, Weinert, Luparell, Conley, and Smith, "Developing a Scholarship Community." 25. Exner and Houk, "Starting the Write Way." 
26. Bradley A. Boucher, Peter A. Chyka, Walter L. Fitzgerald Jr, Lawrence J. Hak, Duane D. Miller, Robert B. Parker, Stephanie J. Phelps, George C. Wood, and Dick R. Gourley, “A Comprehensive Approach to Faculty Development," American Journal of Pharmaceutical Education 70, 2 (2006): 1-6, https://www.ncbi.nlm.nih.gov/pmc/articles/PMC1636916/?tool=pmcentrez.

27. Nilgun Ozdamar Keskin and Abdullah Kuzu, "Development and Testing of a m[mobile]Learning System for the Professional Development of Academics through Design-Based Action Research," International Review of Research in Open and Distributed Learning 16, 1 (2015): 11-21, doi:10.19173/irrodl.v16i1.1613.

28. Alison Park and Erin Nephin, "Practising What We Preach: Developing a Professional Reading Group for the Library Academic Support Team," Collaborate: Libraries in Learning Innovation 1, 1 (2016): 1-3, https://ojs.leedsbeckett.ac.uk/index.php/COL/article/view/4415/4267.

29. Emma Price, Brian Coffey, and Amy Nethery, “An Early Career Academic Network: What Worked and What Didn't," Journal of Further and Higher Education 39, 5 (2015): 680-98, doi:10.1080/0309877X.2014.971106.

30. Deborah Lee, "Mentoring the Untenured Librarian," College \& Research Libraries News 66, 10 (2005): 711-13, 724, http://crln.acrl.org/content/66/10/711.full.pdf+html; Jeannie P. Miller and Candace R. Benefiel, "Academic Librarians and the Pursuit of Tenure: The Support Group as a Strategy for Success," College \& Research Libraries 59, 3 (1998): 26065, doi:10.5860/crl.59.3.260; Richard Sapon-White, Valery King, and Anne Christie, "Supporting a Culture of Scholarship for Academic Librarians," portal: Libraries and the Academy 4, 3 (2004): 407-21, doi:10.1353/pla.2004.0044; Jane Stephens, Laura Sare, Rusty 
Kimball, Margaret Foster, and Joel Kitchens, "Tenure Support Mechanisms Provided by the

Faculty Research Committee at Texas A\&M University Libraries: A Model for Academic

Libraries," Library Management 32, 8-9 (2011): 531-39, doi:10.1108/01435121111187897.

31. Lee, "Mentoring the Untenured Librarian"; Miller, "Academic Librarians and the Pursuit of Tenure."

32. Sapon-White, King, and Christie, "Supporting a Culture of Scholarship"; Stephens, Sare, Kimball, Foster, and Kitchens, "Tenure Support Mechanisms Provided by the Faculty Research Committee.”

33. Sapon-White, King, and Christie, "Supporting a Culture of Scholarship."

34. Lee, "Mentoring the Untenured Librarian"; Sapon-White, King, and Christie, "Supporting a Culture of Scholarship."

35. Sullivan, Leong, Yee, Giddens, and Phillips, "Getting Published."

36. Brannock, Jin, and Zelner, "Researching Your Way out of a Paper Bag."

37. Sullivan, Leong, Yee, Giddens, and Phillips, "Getting Published."

38. Muller, "Developing the Faculty as a Writing Community."

39. Steinert, McLeod, Liben, and Snell, "Writing for Publication in Medical Education."

40. Sullivan, Leong, Yee, Giddens, and Phillips, "Getting Published."

41. Farr, Cavallaro, Civil, and Cochrane, "Taming the Publishing Beast."

42. Sapon-White, King, and Christie, "Supporting a Culture of Scholarship."

43. Price, Coffey, and Nethery, "An Early Career Academic Network."

44. Helen Fallon, "Using a Blended Group Learning Approach to Increase Librarians' Motivation and Skills to Publish," New Review of Academic Librarianship 18, 1 (2012): 7 25, 10.1080/13614533.2012.654673; Steinert, McLeod, Liben, and Snell, “Writing for 
Publication in Medical Education”; Sullivan, Leong, Yee, Giddens, and Phillips, “Getting Published."

45. Liz Walkley Hall and Ian McBain, "Practitioner Research in an Academic Library:

Evaluating the Impact of a Support Group,” Australian Library Journal 63, 2 (2014): 12943, doi:10.1080/00049670.2014.898238.

46. Cirasella and Smale, "Peers Don't Let Peers Perish"; Sapon-White, King, and Christie, "Supporting a Culture of Scholarship."

47. Cumbie, Weinert, Luparell, Conley, and Smith, "Developing a Scholarship Community"; Herman, Abate, and Walker, "Faculty Writing Retreat."

48. Farr, Cavallaro, Civil, and Cochrane, "Taming the Publishing Beast"; Hampton-Farmer, Laverick, Denecker, Tulley, Diederich, and Wilgus, "Growing a Faculty Writing Group on a Traditionally Teaching-Focused Campus."

49. Steinert, McLeod, Liben, and Snell, "Writing for Publication in Medical Education."

50. Stephens, Sare, Kimball, Foster, and Kitchens, “Tenure Support Mechanisms Provided by the Faculty Research Committee."

51. Boucher, Chyka, Fitzgerald, Hak, Miller, Parker, Phelps, Wood, and Gourley, “A Comprehensive Approach to Faculty Development."

52. Hampton-Farmer, Laverick, Denecker, Tulley, Diederich, and Wilgus, "Growing a Faculty Writing Group on a Traditionally Teaching-Focused Campus.”

53. Jeanne F. Voyles and Robyn Huff-Eibl, "Needs Assessment: Planning, Implementation, and Action," in Staff Development: A Practical Guide, ed. Andrea Wigbels Stewart, Carlette Washington-Hoagland, and Carol T. Zsulya, 4th ed. (Chicago: American Library Association, 2014), 10. 
Table 1. Sample of session attendance over one year

\begin{tabular}{|c|c|c|c|c|c|}
\hline Rank & $\begin{array}{l}1 \text { or more } \\
\text { sessions }\end{array}$ & $\begin{array}{l}2 \text { or more } \\
\text { sessions }\end{array}$ & $\begin{array}{l}3 \text { or more } \\
\text { sessions }\end{array}$ & $\begin{array}{l}4 \text { or more } \\
\text { sessions }\end{array}$ & $\begin{array}{l}5 \text { or more } \\
\text { sessions }\end{array}$ \\
\hline $\begin{array}{l}\text { Assistant } \\
\text { Librarian } \\
(n=16)\end{array}$ & $\begin{array}{l}12 \\
(75 \%)\end{array}$ & $\begin{array}{l}7 \\
(44 \%)\end{array}$ & $\begin{array}{l}5 \\
(31 \%)\end{array}$ & $\begin{array}{l}4 \\
(25 \%)\end{array}$ & $\begin{array}{l}1 \\
(6 \%)\end{array}$ \\
\hline $\begin{array}{l}\text { Associate } \\
\text { Librarian } \\
n=31\end{array}$ & $\begin{array}{l}14 \\
(45 \%)\end{array}$ & $\begin{array}{l}8 \\
(26 \%)\end{array}$ & $\begin{array}{l}7 \\
(23 \%)\end{array}$ & $\begin{array}{l}4 \\
(13 \%)\end{array}$ & $\begin{array}{l}2 \\
(6 \%)\end{array}$ \\
\hline
\end{tabular}

$\begin{array}{llllll}\begin{array}{l}\text { Librarian } \\ \mathrm{n}=10\end{array} & 5 & 3 & 2 & 1 & 1 \\ & (50 \%) & (30 \%) & (20 \%) & (10 \%) & (10 \%)\end{array}$


Table 2. Sample of data from session evaluations

\begin{tabular}{llllllll} 
Date & Topic & Presenter Attendance & $\begin{array}{l}\text { Survey } \\
\text { Respondents }\end{array}$ & $\begin{array}{l}\text { Beneficial } \\
\text { Score }\end{array}$ & $\begin{array}{l}\text { Newness } \\
\text { Score }\end{array}$ & $\begin{array}{l}\text { Change } \\
\text { Score }\end{array}$ \\
\hline $\mathbf{9 / 1 1}$ & $\begin{array}{l}\text { Committee } \\
\text { Leadership }\end{array}$ & S.B. & 13 & $9(69 \%)$ & 5.56 & 4.67 & 5.11 \\
$\mathbf{1 1 / 3}$ & $\begin{array}{l}\text { Developing } \\
\text { Research } \\
\text { Topics }\end{array}$ & C.H. & 11 & $8(72 \%)$ & 5.50 & 4.25 & 4.50 \\
\end{tabular}

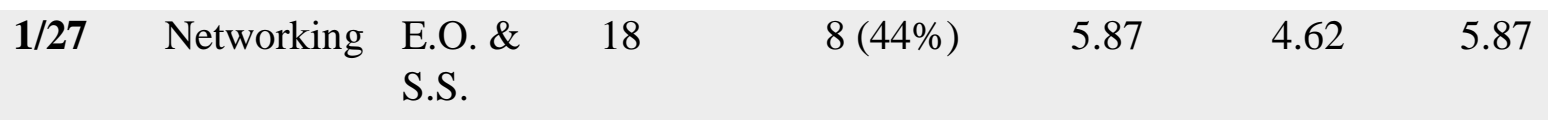


Table 3. Sample feedback for Peer Reviewer Service

\begin{tabular}{c} 
Survey Question $\begin{array}{c}\text { Average } \\
\text { Response } \\
(n=5)\end{array}$ \\
\hline
\end{tabular}

How beneficial to your paper was the feedback that 7 you received through the Peer Reviewer Service? (Scale: $0=$ not beneficial; $8=$ could not succeed without it)

How much will the feedback change what you do?

(Scale: $0=$ no change at all; $8=$ changes what I do completely) 
Table 4. Sample Activities Survey result

\begin{tabular}{lll} 
Respondents & $\begin{array}{l}\text { Total Presentations } \\
\text { Delivered }\end{array}$ & Average per Respondent \\
\hline Less Active & 26 & 2.6
\end{tabular}

Less Active

Attending 5 or fewer events* $(n=10)$

More Active

23

2.875

Attending more than 5 events* $(n=8)$

* "Events" are defined as either development sessions or participation in peer-review services. 